\title{
THE ORIGIN OF ULTRAMAFIC (GROUP A) ECLOGITES: Nd \& Sr ISOTOPIC EVIDENCE FROM THE OBNAZHENNAYA KIMBERLITE, YAKUTIA
}

Snyder, G.A. ${ }^{1}$, Keller, R.A. ${ }^{1}$, Taylor, L.A. ${ }^{1}$, Remley, D. ${ }^{1}$, Halliday, A.N. ${ }^{2}$ \& Sobolev, N. ${ }^{3}$

1. Planetary Geosciences Institute, Univ. of Tennessee, Knoxville, TN 37996 USA; gasnyder@utk.edu

2. Department of Geological Sciences, University of Michigan, Ann Arbor, MI 48109

3. Institute of Mineralogy \& Petrog., Siberian Branch, Russian Academy of Sciences, Novosibirsk, Russia

\section{Introduction}

Although many eclogite xenoliths are thought to be fragments of subducted oceanic crust (e.g., Ireland et al., 1994), there has always been a group of eclogites, with demonstrably higher $\mathrm{Cr}$ values, and elevated $\mathrm{Mg \# s,} \mathrm{which} \mathrm{exhibit} \mathrm{little,} \mathrm{if} \mathrm{any,} \mathrm{evidence} \mathrm{of} \mathrm{oceanic} \mathrm{crustal} \mathrm{affinity.} \mathrm{These} \mathrm{eclogites,}$ the so-called Group A eclogites (a la Coleman et al., 1965), have always remained an enigma in eclogite petrogenesis. Some workers have concluded that these xenoliths, indeed, are samples direct from and formed in the mantle (e.g., MacGregor \& Manton, 1986; Smyth \& Caporuscio, 1989; Taylor \& Neal, 1989). Others have speculated that these samples may also be of oceanic affinity and are remnants of deeper, ultramafic, oceanic crust, akin to the harzburgitic to gabbroic sections of ophiolites which also contain pods of chromite (see Snyder et al., 1997, for a discussion). This radiogenic isotopic study of Group A eclogite xenoliths from the Obnazhennaya kimberlite, Yakutia, combined with data from Group A eclogites worldwide, is an attempt to solve the problem of these enigmatic eclogites.

The Obnazhennaya kimberlite pipe is located within the lower Olenek province, which occupies the extreme northeastern portion of the Siberian platform. This province is one of seven recognized that compose the Siberian platform (Rosen et al., 1994). The Obnazhennaya kimberlite intruded late Proterozoic (Sinian) dolomites during the late Mesozoic (Cretaceous). Evidence for this comes from the occurrence of a beleminite in the kimberlite near the contact between the pipe and wall rock. It has been further corroborated by isotopic dating of groundmass phlogopite and zircons from the pipe and nearby alluvial deposits (Sobolev, 1977).

\section{Petrography \& Mineral Chemistry}

The so-called Group A eclogites from Obnazhennaya contain a substantial amount of orthopyroxene, from 1.5 to 12.5 modal\% (Qi et al., 1994). The two samples analyzed in this study, O-81 and O-84, have the greatest abundance of orthopyroxene, 11.8 and 12.5 modal\%, respectively. Thus, these samples are not eclogites, sensu strictu, but garnet websterites. Mineral separates in O-81 are complexly exsolved with garnet in clinopyroxene and rutile in garnet. An in-depth study of the petrography and mineral chemistry of these xenoliths is found in Qi et al. (1994, 1997) and Keller et al. (1998, this volume).

\section{Nd \& Sr Isotopic Compositions of Minerals \& Sm-Nd Ages}

The $\mathrm{Nd}$ and $\mathrm{Sr}$ isotopic compositions of mineral separates in O-81 offer a confounding set of data. We analyzed two clinopyroxene separates in this sample, one with a small proportion of exsolved garnet ("cpx") and one with a greater proportion of exsolved garnet ("ex/cpx"). The "ex/cpx" separate $\left({ }^{87} \mathrm{Sr} /{ }^{86} \mathrm{Sr}=0.703399 \pm 18\right)$ does not have a more elevated ${ }^{87} \mathrm{Sr} /{ }^{86} \mathrm{Sr}$ than "cpx" $(=0.703447 \pm 23)$, as might be expected from the relatively radiogenic nature of the garnet separate $(=0.703684 \pm 20)$. Although "ex/cpx" has slightly lower $\mathrm{Sm}$ and $\mathrm{Nd}$ abundances than "cpx", the ${ }^{147} \mathrm{Sm} /{ }^{144} \mathrm{Nd}$ ratios of the two separates are virtually indistinguishable. This is unexpected, because of the elevated ${ }^{143} \mathrm{Nd} /{ }^{144} \mathrm{Nd}(0.517222 \pm 13)$ of the garnet separate. The ${ }^{143} \mathrm{Nd} /{ }^{144} \mathrm{Nd}$ of these two clinopyroxene separates are similar, with $0-81 \mathrm{cpx}$ having a ratio of $0.512775 \pm 11$ and $0-81 \mathrm{ex} / \mathrm{cpx}$ having a ratio of $0.512647 \pm 12$.. The data from mineral separates in $\mathrm{O}-84$ are equally complex. 
Internal, garnet-clinopyroxene, $\mathrm{Sm}-\mathrm{Nd}$ isochrons yield ages of $1070 \pm 5 \mathrm{Ma}$ (initial $\varepsilon_{\mathrm{Nd}}=$ $+3.9)$ for $0-81$ and $1237 \pm 3 \mathrm{Ma}\left(\varepsilon_{\mathrm{Nd}}=-12.4\right)$ for $0-84$. However, we have also analyzed orthopyroxene and serpentine (=olivine?) from sample 0-84. A four-mineral isochron for this sample defines a similar age $(1199 \pm 225 \mathrm{Ma})$, but with a higher initial $\varepsilon_{\mathrm{Nd}}(=-8.5)$. Samples enriched to the degree of 0-84 are uncommon, but have been recognized in diamond-bearing pipes (Mir and Udachnaya) from Yakutia. These two samples alone suggest a major mid- to late-Proterozoic eclogite formation event in the lower Olenek province that included both depleted and enriched mantle.

\section{The Character of Group A Eclogites Worldwide}

We have combined our new mineral-chemical and radiogenic isotopic data on Group A eclogites from Obnazhennaya with a compilation of data on Group A eclogites worldwide. Several features are noteable about these xenoliths.

Petrography \& Mineral Chemistry -- Group A eclogites often contain accessory orthopyroxene, either as distinct grains (thus, the use of the term garnet websterite) or as exsolution lamellae, and/or serpentine alteration (suggesting the presence of olivine at some time), as noted for those samples from Obnazhennaya, Siberia (Qi et al., 1994), Bellsbank (Shervais et al., 1988; Taylor \& Neal, 1989; Jerde et al., 1993) and Kaalvallei (Viljoen, 1994) in South Africa, and Orapa, Botswana (Shee and Gurney, 1979). Compared to omphacitic pyroxenes in Groups $\mathrm{B}$ and $\mathrm{C}$ eclogites, which have $\mathrm{Na}_{2} \mathrm{O}$ from 2.6 to $9.1 \mathrm{wt} \%$, Group A clinopyroxenes are notably depleted in $\mathrm{Na}_{2} \mathrm{O}(\leq 2.7 \mathrm{wt} \%)$. Clinopyroxenes in Group A eclogites also have $\mathrm{Mg \# s}(\geq 86)$ which are at the high end of Groups $\mathrm{B}$ and $\mathrm{C}$, and higher $\mathrm{CaO}$, in keeping with lower $\mathrm{Na}_{2} \mathrm{O}$.

Oxygen Isotopes -- Group A eclogites worldwide do not exceed the mantle values for oxygen isotopes $\left(\delta^{18} \mathrm{O}=5.7 \pm 0.5 \%\right)$, although their values can fall below the mantle range, i.e. down to 3.7\% (only in South Africa; Viljoen, 1994). However, among eclogite suites from the same pipe, Group A eclogites do not define the lowest values. Group A eclogites from Siberia are always within the mantle range (Qi et al., 1994; Snyder et al, 1995).

Radiogenic Isotopes -- Whereas Groups $\mathrm{B} / \mathrm{C}$ eclogites exhibit broad ranges in present-day isotopic composition $\left({ }^{87} \mathrm{Sr} /{ }^{86} \mathrm{Sr}\right.$

$=0.7015$ to $0.7215 ; \varepsilon_{\mathrm{Nd}}=0$ to +235), Group A eclogites occur over a more restricted range that is on average less radiogenic $\left({ }^{87} \mathrm{Sr} /{ }^{86} \mathrm{Sr}=0.7029\right.$ to 0.7062 , $\varepsilon_{\mathrm{Nd}}=-19$ to +8.3$)$ (MacGregor $\&$ Manton, 1986; Shervais et al., 1988; Neal et al., 1990; ${ }^{\circ}$ Viljoen, 1994; Snyder et al., 1997). Thus, although Group A eclogites are generally less radiogenic, Group B/C eclogites have the lowest ${ }^{87} \mathrm{Sr} /{ }^{86} \mathrm{Sr}$ within a

given pipe. (i.e., at Udachnaya

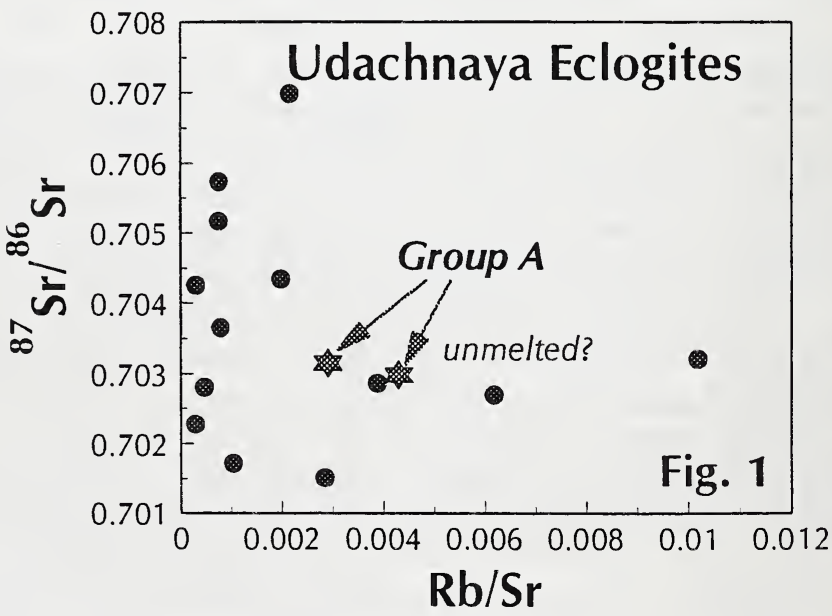

the lowest ${ }^{87} \mathrm{Sr} /{ }^{86} \mathrm{Sr}$ values are 0.7015 and 0.7017 from two Group B/C eclogites). This may in part be a consequence of the lower $\mathrm{Rb} / \mathrm{Sr}$ in Group $\mathrm{B} / \mathrm{C}$ eclogites and the antiquity of the samples. If a melting event 
eclogite formation (Ireland et al, 1994), say during subduction in the Archean, Group B/C eclogites may have been partially melted, whereas Group A eclogites were not melted (or to a lesser degree). Thus, Group $\mathrm{B} / \mathrm{C}$ eclogites would have lost $\mathrm{Rb}$ relative to $\mathrm{Sr}$, lowering the $\mathrm{Rb} / \mathrm{Sr}$ and effectively arresting the ${ }^{87} \mathrm{Sr} /{ }^{86} \mathrm{Sr}$ near the initial value (Fig. 1). This may also explain why Group A eclogites tend to have lower $\mathrm{Sm} / \mathrm{Nd}$ ratios (e.g., Viljoen, 1994, Snyder et al., 1997) than Group B/C eclogites, which are residues of partial melting (Fig. 2).

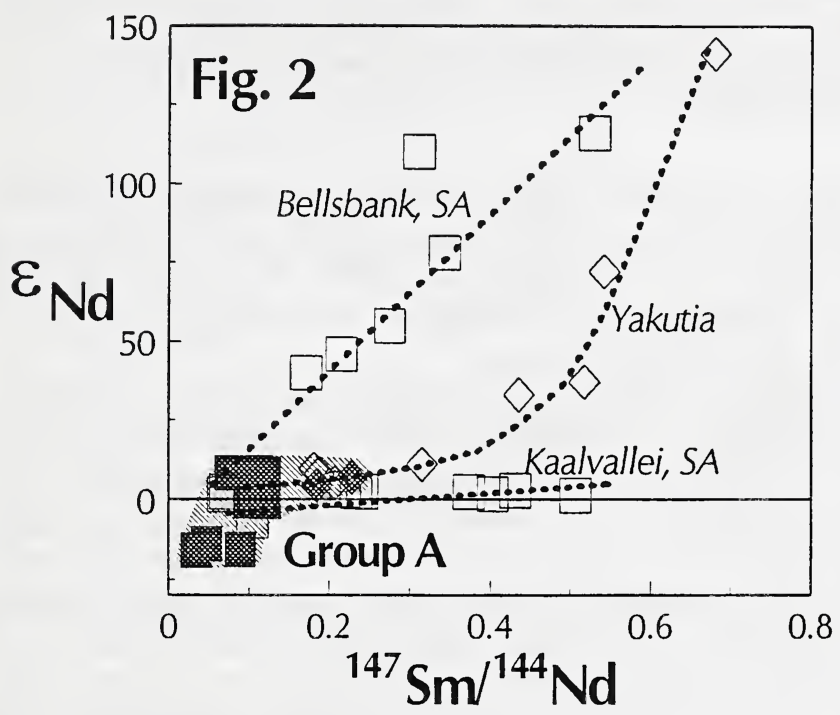

References

Coleman, R.G., Lee, E.D., Beatty, L.B., Brannock, W.W., 1965, Eclogites and eclogites: their differences and similarities: Geol. Soc. Amer. Bull. 76, 483-508.

Ireland, T.R., Rudnick, R.L., and Spetsius, Z.V., 1994, Trace elements in diamond inclusions from eclogites reveal a link to Archean granites: Earth and Planetary Science Letters 128, 199213.

Jerde, E.A., Taylor, L.A., Crozaz, G., and Sobolev, N.V., 1993, Exsolution of garnet within clinopyroxene of mantle eclogites: major- and trace-element chemistry: Contrib. Mineral. Petrol. 114, 148-159.

Keller, R.A., Remley, D.A., Snyder, G.A., Taylor, L.A., and Sobolev, N.V., 1998, Mantle xenoliths from the Obnazhennaya kimberlite, Siberia: 7th Int'1 Kimberlite Conf. Abstracts, this volume

MacGregor, I.D. and Manton, W.I., 1986, Roberts Victor eclogites: ancient oceanic crust: Journal of Geophysical Research 91, 14063-14079.

Neal, C.R., Taylor, L.A., Davidson, J.P., Holden, P., Halliday, A.N., Nixon, P.H., Paces, J.B., Clayton, R.N., and Mayeda, T.K., 1990, Eclogites with oceanic crustal and mantle signatures from the Bellsbank kimberlite, South Africa, part 2: Sr, Nd, and O isotope geochemistry: Earth Planet. Sci. Lett. 99, 362-379.

Qi, Q., Taylor, L.A., Snyder, G.A., and Sobolev, N.V., 1994, Eclogites from the Obnazhennaya kimberlite pipe, Yakutia, Russia: Int'l. Geol. Rev. 36, 911-924.

Qi, Q., Taylor, L.A., Snyder, G.A., Clayton, R.N., Makeda, T.K., and Sobolev, N.V., 1997, Detailed petrology and geochemistry of a rare corundum eclogite xenolith from Obnazhennaya, Yakutia: Proc. Sixth Int'i. Kimberlite Conf., 247-260.

Rosen, O.M., Condie, K.C., Natapov, L.M., and Nozhkin, A.D., 1994, Archean and early Proterozoic evolution of the Siberian craton: A preliminary assessment: In Condie, K.C., editor, Archean Crustal Evolution, Elsevier, Amsterdam, 411-459.

Shee, S.R., and Gurney, J.J., 1979, The mineralogy of xenoliths from Orapa, Botswana: In Boyd, F.R. and Meyer, H.O.A., editors, The Mantle Sample: Inclusions in Kimberlites and Other Volcanics, AGU, Wash., DC, 37-49.

Shervais, J.W., Taylor, L.A., Lugmair, G.W., Clayton, R.N., Mayeda, T.K., and Korotev, R.L., 1988, Early Proterozoic oceanic crust and the evolution of subcontinental mantle: Eclogites and related rocks from southern Africa: Geol. Soc. Amer. Bull. 100, 411-423.

Smyth, J.R. and Caporuscio, F.A., 1984, Petrology of a suite of eclogite inclusions from the Bobbejaan kimberlite: II. Primary phase compositions and origin: In Komprobst, J., editor, Kimberlites II. The mantle and crust-mantle relationships, 121-131.

Snyder, G.A., Taylor, L.A., Jerde, E.A., Clayton, R.N., Mayeda, T.K., Deines, P., Rossman, G.R., and Sobolev, N.V., 1995, Archean mantle heterogeneity and the origin of diamondiferous eclogites, Siberia: Evidence from stable isotopes and hydroxyl in garnet: Amer. Mineral. 80, 799-809.

Snyder, G.A., Taylor, L.A., Crozaz, G., Halliday, A.N., Beard, B.L., Sobolev, V.N., and Sobolev, N.V., 1997, The origins of Yakutian eclogite xenoliths: Jour. Petrol. 38, 85-113.

Taylor, L.A. and Neal, C.R., 1989, Eclogites with oceanic crustal and mantle signatures from the Bellsbank kimberlite, South Africa, Part I: Mineralogy, petrography, and whole rock chemistry: Jour. Geol. 97, 551-567.

Viljoen, K.S., 1994, The petrology and geochemistry of a suite of mantle-derived eclogite xenoliths from the Kaalvallei kimberlite, South Africa: Unpublished Ph.D. thesis, Univ. Witwatersrand, Johannesburg, 160 pp. 